\title{
Examining the Sense of Responsibility of the Primary School Students in Terms of School Satisfaction and School Attachment ${ }^{1}$
}

\author{
Halil İbrahim Sağlam² $\quad$ Büşra Kaplanc1 ${ }^{3}$
}

\begin{abstract}
This study was conducted to examine the sense of responsibility of the primary school students in terms of school satisfaction and school attachment. The study group of the research consists of 844 fourth grade students (417 girls and 427 boys) attending a primary school in Sakarya during 2017-2018 academic year. The data of the research carried out using a relational screening model, which is among the quantitative research methods, were collected with "Personal Information Form", "Responsibility Scale", "Children's Overall Satisfaction with Schooling Scale" and "School Attachment Scale for Children and Adolescents". The results of the study presented that there is a positive and a significant relationship between the responsibility levels of the students and the school satisfaction and school attachment and that the responsibilities of the students differ significantly according to the regulation and responsibility perceptions of the students.
\end{abstract}

Keywords: Responsibility, primary school, value, school satisfaction, school attachment

\section{INTRODUCTION}

One of the objectives of Turkish Education System is to raise individuals who have balanced and healthy personality and physically, mentally, morally and emotionally strong characters, who can think freely and scientifically, who have broad visions, who show respect to the human rights and who honor identity and attempt, who have social responsibility, who are positive, creative and productive (URL, 1), who are equipped with specific values and who act according to these values after internalizing them besides developing their knowledge and skill (Karakuş, Kartal, \& Çağlayan, 2016). The values developing the behaviors, perspectives and characteristics of the individuals are among the most significant components of the social life and social culture. Within this framework, values are thought to be the most effective connections ensuring the togetherness of the individuals of a society (Uzunkol, 2015).

The concept of "sense of responsibility" in the below-mentioned sentence can only be seen in the individuals with self-confidence and self-control. "The democracy awareness all citizens should possess, the sense of responsibility towards the knowledge, understanding and actions on the government of a country and respect to the moral values must be given to the students effectively in any educational activity for a strong and consistent, free and democratic social order and its continuity..." (URL, 2).

Therefore, the teachers should raise their students as individuals who can stand on their own feet, who are self-confident, who are aware of their duties and responsibilities towards themselves and towards the society (Tepecik, 2008). Developing the values indicates explicitly or implicitly in the preschool

\footnotetext{
1 This work was produced from the second author's master's thesis, which was supervised by the first author.

2 Prof. Dr., Istanbul Medeniyet University, Faculty of Educational Sciences, halil.saglam@medeniyet.edu.tr

${ }^{3}$ MA, Sakarya University, Institute of Educational Sciences, bkaplanci@sakarya.edu.tr
} 
curriculum, contributing to the moral developments of the students and affecting their characteristics positively are among the most prominent roles of the schools (Akbaş, 2008).

Family which is considered as the first educational environment of a child provides a basis not only for establishing the recognition of moral issues but also for teaching some values such as love, respect, trust, responsibility and so on. Therefore, developing the senses of the children in the family environment, supporting their interests by the family members and improving their skills, abilities and emotions at home are vital (Hökelekli \& Gündüz, 2007). These values which are planned to be established later in the school when the child starts school are interrelated. However, sense of responsibility which is a prerequisite for success and self-confidence in the psychosocial development of the child is also very important and effective for creating social awareness. Satisfaction in professional life, within the family and in any stage of the life is probable with fulfilling one's responsibilities (Tepecik, 2008). "Responsibility is not an innate feeling; it is gained by providing appropriate conditions. To establish a sense of responsibility the individual should be raised in an environment where he/she takes responsibilities. If the individual weren't given the opportunity of making his/her choices or being responsible of the consequences of his/her choices, the sense of responsibility wouldn't establish" (Cüceloğlu, 2002: 211).

Responsibility is fulfillment of the developmental tasks according to the age, gender and development level of the child starting from early childhood (Yavuzer, 1997). Assigning responsibilities which are appropriate to the development level of the child and thus which can be accomplished by the child in the family is crucial for the development of the child. Responsible children can be described as the individuals who can use their sources consciously, who can make their own decisions, who admit the consequences of their own feelings, thoughts and behaviors, who are also aware of the rights and liabilities of the others, who take the responsibility of their own actions, who are compatible with the environment and hardworking. On the other hand, irresponsible children do not fulfill their duties, do not blame others for their own mistakes, do not stand behind their own actions, do not perform the commitments either to themselves or to the others, are lazy, ill-tempered and trouble-making individuals (Güner \& Selçuk, 2004).

Responsibility training is a must for the individuals to take the consequences of their thoughts and actions, to fulfill their responsibilities at every stage of their lives, to make conscious choices, to make their own decisions, to take responsibilities, to make their lives more liveable with their actions, to be happy individuals by adapting to social life, to fulfill their duties, to have a proper social environment and to continue their lives as healthy individuals (Önal, 2005).

The child who can take responsibilities and who fulfills his/her responsibilities displays not only a remarkable academic success but also a better relationship with his/her friends. School experiences like a developed relationship with the other people at schools, feeling competent as a learner, being self-reliant and self-governing are all related to positive school attitude (Baker, Dilly, Aupperlee, \& Patil, 2003). Positive experiences at school affect the attitude towards school positively as well. This positive attitude and approach supports the school attachment and school love of the child.

School attachment means believing in being valuable and respected as a member of the school (Roeser, Midgley, \& Urdan, 1996; Samdal, Wold, \& Bronis, 1999). In other words, school attachment can be 
described as having positive feelings towards school, feeling positively on education, being a part of the school environment and having a nice relationship with the school staff and with other students, attending school regularly, attending extracurricular social activities, spending extra time for school activities, agreeing with the decisions taken both in the classroom and in the school, identifying his/her own learning objectives and speaking out one's thoughts within the classroom (Mengi, 2011). School satisfaction which is a sub dimension of life satisfaction is thought as an element of both subjective wellbeing and global life satisfaction (Casas, Bello, González, \& Aligué, 2013).

It is observed that the students with high school attachment feeling have a better relationship with their teachers and friends, develop a higher self-esteem and are generally more satisfied with their lives. It is established that while anxiety, loneliness and absenteeism levels are lower, the positive behaviors, internal motivation and academic success levels are higher among the students with higher school attachment level (Cemalcilar, 2010). Therefore, it is assumed that the quality time spent in the school and the successful work might affect the school attachment and school satisfaction positively and that this can support the desire to take responsibilities.

There are some studies on responsibility in the literature. Within this concept, in his study Acar (2012) came to the conclusion that existentialist approach based responsibility training program has a positive effect on the students. Likewise, Aydoğan and Gündoğdu (2015) observed that the students fulfill the action they wanted most, that they act more responsibly in the action they choose and that the there is a decrease in the unwanted behaviors of the students who do not do their homework regularly in their studies. In their studies Deveci and Selanik Ay (2009) reached thirteen themes which are listed as responsibility, diligence, human relationships, self-control, national values, being honorable, cleanliness, consistence, tolerance, sharing, mercy, honesty and politeness - and as it is seen being responsible is among these themes. In their studies which examines the relationship between responsibility and education Taşdemir and Dağıstan (2014) stated that successful students fulfill any kind of responsibilities and that the parents use methods like information, reminders, follow ups and feedbacks. Yontar (2007) mentioned that although some of the teachers adopted punishment methods for the students who do not fulfill their responsibilities, these methods are effective only in the short term. Apart from the studies in the literature, the main objective of this study is to examine the sense of responsibility of the primary school students in terms of school satisfaction and school attachment. In line with this objective the answers of the following questions are sought:

1. Do the school satisfaction and school attachment of the 4th grade primary school students predict the responsibility levels?

2. Do the responsibility levels of the 4th grade primary school students differ according to their own perception of regulation?

3. Do the responsibility levels of the 4th grade primary school students differ according to their own perception of responsibility? 


\section{METHOD}

This study was conducted using relational screening model. "Screening models are the research models that aim to collect data to determine the certain properties of a group." (Büyüköztürk, Kılıç Çakmak, Akgün, Karadeniz, \& Demirel, 2014).

\section{Study Group}

The study group of the research consists of 844 fourth grade students ( 417 girls and 427 boys) attending primary school in Sakarya during 2017-2018 academic year. The study group was chosen from the state and private schools in Adapazarı and Serdivan districts of Sakarya province via convenience sampling method.

\section{Data Collection Tools}

The data of this study was collected using "Personal Information Form", "Responsibility Scale (RS)", "Children's Overall Satisfaction with Schooling Scale (COSSS)" and "School Attachment Scale for Children and Adolescents (SAS-CA)". The gender of the students, their own regulation and responsibility perceptions were in the "Personal Information Form".

"Responsibility Scale (RS)" which is a likert type scale with 24 items was developed by Golzar (2006) to determine the responsibility levels of the primary school students. The students were asked to choose one of the options for each item as (1) Never, (2) Sometimes, (3) Always. While the maximum score of the scale is 72 , the minimum score can be 24 .

"Children's Overall Satisfaction with Schooling Scale (COSSS)" which was a one-dimension scale consisting 6 items was developed by Randolph, Kangas and Ruokamo (2009) to evaluate the overall school satisfactions of the primary school students. As each item in the scale is scored from 1 to 5 points, the total score of the scale is between 6 and 30. A high score implies a higher education level at school.

School Attachment Scale for Children and Adolescents (SAS-CA) was developed by Hill (2006) to find out the school attachment levels of the children and adolescents. The scale original name of which is "School Attachment Scale" (SAS) consists of items on teacher, friend and school attachment. There are 15 items in the original scale and it was adapted to Turkish by Savi (2011). The recent form of the scale has 13 items. While the test-retest reliability coefficient for the whole scale is .85 , split-half reliability coefficient is .78. The sub dimensions of the scale are called "school attachment", "teacher attachment" and "friend attachment" respectively. It is a 5-likert type scale. The score of the scale ranges from 13 to 65. The higher score from the scale displays that school attachment is high.

\section{Collection and Analysis of the Data}

The assessment tools were taken to the primary schools in Adapazarı and Serdivan districts of Sakarya province by the researches after the ethics committee report and necessary research permission had been obtained. The assessment tools were applied to the 4th grade students after the interview with the school administration. The data were analyzed with correlation, regression analysis, $t$-test and one-way analysis of variance in accordance with the sub problems of the study. Within this regard the relationships between the variables were determined with correlation analysis. The fact that whether the independent variables found out to be related to the dependent variable according to the result of the 
correlation analysis predicts the dependent variable significantly or not was examined with regression analysis. Unrelated sample t-test was used to determine whether the dependent variable differs in terms of the independent variables with category level 2.

If the variances are homogenous, one-way analysis of variance was used in the analysis to determine whether the dependent variables differ in terms of independent variables which has a category level more than 2 and Welch test was used if the variances are not homogenous. The homogeneity of the variances was determined with Levene statistical test. When the results of the one-way analysis of variance were significant, Scheffe test was used to find out from which groups the difference derive. When Welch test was used as the variances are not homogenous, Tamhane's T2 test was used for paired comparisons.

\section{FINDINGS}

The findings are examined based on the sub problems.

The Relationship between Responsibility and School Attachment and School Satisfaction

Table 1.

The result of the Correlation Analysis between the Responsibility Levels of the Students and Their School Satisfaction and School Attachment

\begin{tabular}{llll}
\hline Variables & 1 & 2 & 3 \\
\hline 1. Responsibility & 1 & 1 & \\
2. School Satisfaction & $.11^{* *}$ & $.08^{*}$ & 1 \\
3. School Attachment & $.38^{* *}$ & 20.04 & 60.75 \\
$\bar{X}$ & 65.99 & 10.01 & 4.51 \\
SD & 4.47 & & \\
\hline
\end{tabular}

${ }^{* *} p<.01,{ }^{*} p<.05$

Examination of Table 1 displays a positive and significant relationship between the responsibility levels of the students and school satisfaction $(r=.11)$ and school attachment $(r=.38)$. In accordance with this finding the fact that whether school satisfaction and school attachment predicts the responsibility significantly was examined with regression analysis. Before the data of the study were subjected to regression analysis, the data set was evaluated with regard to assumptions of the regression analysis and the obtained results were presented in Figure 1 and Table 2. Examination of the Mahalanobis distance values, kurtosis, skewness values and normal scatter graph gives whether the data fit the regression analysis. In this context, first the Mahalanobis distance values were calculated for determining the existence of multivariate extreme values. The values were evaluated according to $p<.01$ significance level and they was confirmed that there weren't any data damaging the "normality" and 
"linearity" assumption in the data set. Then other scatter indicators (kurtosis, skewness values and normal scatter graph) were examined to decide whether the data set fits the regression analysis.

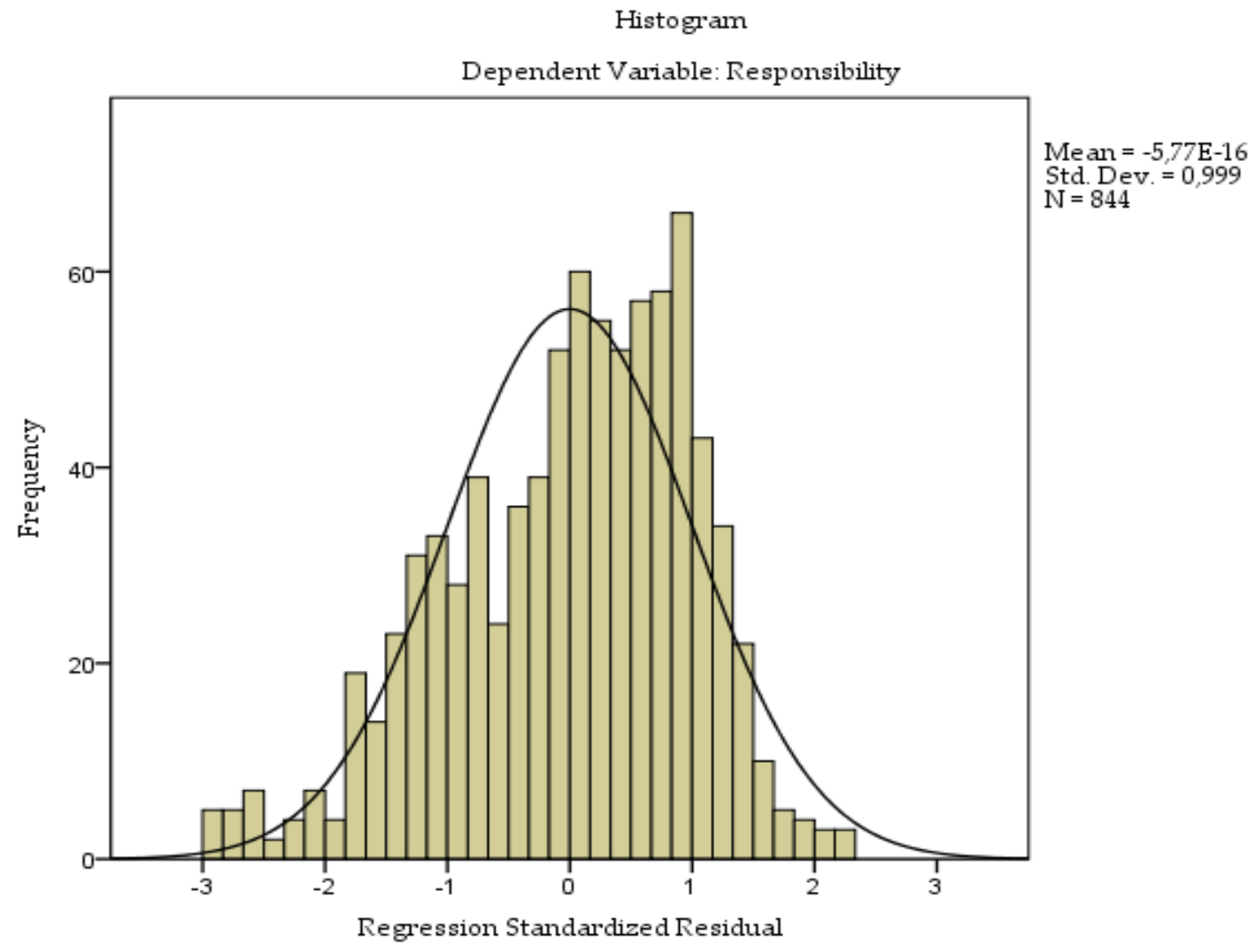

Figure 1. Normal Scatter Graph

Table 2.

Findings on the Regression Analysis Assumptions for the Prediction Levels of School Satisfaction and School Attachment in terms of Responsibility

\begin{tabular}{llll}
\hline Variables & Skewness & Kurtosis & VIF \\
\hline Responsibility & -.607 & -.332 & \\
School Satisfaction & -.412 & -1.614 & 1,007 \\
School Attachment & -1.114 & .349 & 1,007 \\
\hline
\end{tabular}


Table 3.

Regression Test Results for the Prediction Levels of School Satisfaction and School Attachment in terms of Responsibility

\begin{tabular}{|c|c|c|c|c|c|c|c|c|c|c|}
\hline \multirow{2}{*}{$\begin{array}{l}\text { Dependent } \\
\text { Variable }\end{array}$} & \multirow{2}{*}{ Predictor Variables } & \multirow{2}{*}{$B$} & \multirow{2}{*}{ SE } & \multirow{2}{*}{$\beta$} & \multirow{2}{*}{$t$} & \multirow{2}{*}{$F$} & \multirow{2}{*}{$p$} & \multicolumn{2}{|c|}{ Correlation } & \multirow{2}{*}{$-R^{2}$} \\
\hline & & & & & & & & Partial & Semi-part. & \\
\hline \multirow{3}{*}{ Responsibility } & Fixed & 42.500 & 1.918 & & 22.154 & & .000 & & & \\
\hline & School Attachment & .374 & .032 & .378 & 11.880 & 76.67 & .000 & .379 & .377 & .15 \\
\hline & School Satisfaction & .036 & .014 & .080 & 2.525 & & .012 & .087 & .080 & \\
\hline
\end{tabular}

On examining Table 3 it can be seen that school attachment $(\beta=.378)$ and school satisfaction $(\beta=.080)$ predicts responsibility statistically significant. According to this finding it can be stated that the regression model containing school attachment and school satisfaction predicts $15 \%$ of responsibility.

\section{Relationship between Regulation Perception and Responsibility}

To determine whether the responsibility levels of the students differ significantly according to regulation perception, the homogeneity of the variance of the scores were found out using Levene test. As the test results stated that the variances are homogenous $[F(2,834)=8.824, p=.000]$, the results of the Welch test, which is an alternative to one-way analysis of variance, were taken into consideration. It is also found out that the results obtained from this test were crucial [Welch Test: $F(2,73.078)=79.312 ; p=$ .000]. Besides, to determine which groups lead the significant difference for the responsibility levels Tamhane's T2 test, which do not deal with the assumption of homogeneity of the variances, was used and the related findings are presented in Table 5. Likewise, the findings on the responsibility levels of the students based on the regulation perception were illustrated in Figure 2.

Table 4.

Descriptive Analysis Results on the Regulation perceptions of the students

\begin{tabular}{|c|c|c|c|c|c|c|c|}
\hline \multirow{2}{*}{$\begin{array}{l}\text { Regulation } \\
\text { Perception }\end{array}$} & \multirow{2}{*}{$\mathrm{N}$} & \multirow{2}{*}{$\overline{z^{-}}$} & \multirow{2}{*}{ SD } & \multicolumn{2}{|c|}{ 95\% Confidence Interval } & \multirow{2}{*}{$\begin{array}{l}\text { Lowest } \\
\text { Score }\end{array}$} & \multirow{2}{*}{$\begin{array}{l}\text { Highest } \\
\text { Score }\end{array}$} \\
\hline & & & & Lower Limit & Upper Limit & & \\
\hline Low & 31 & 63.43 & 4.56 & 61.66 & 65.19 & 55 & 72 \\
\hline Medium & 491 & 64.67 & 4.35 & 64.29 & 65.06 & 53 & 72 \\
\hline High & 322 & 68.16 & 3.69 & 67.75 & 68.56 & 53 & 72 \\
\hline Total & 844 & 65.96 & 4.47 & 65.66 & 66.27 & 53 & 72 \\
\hline
\end{tabular}




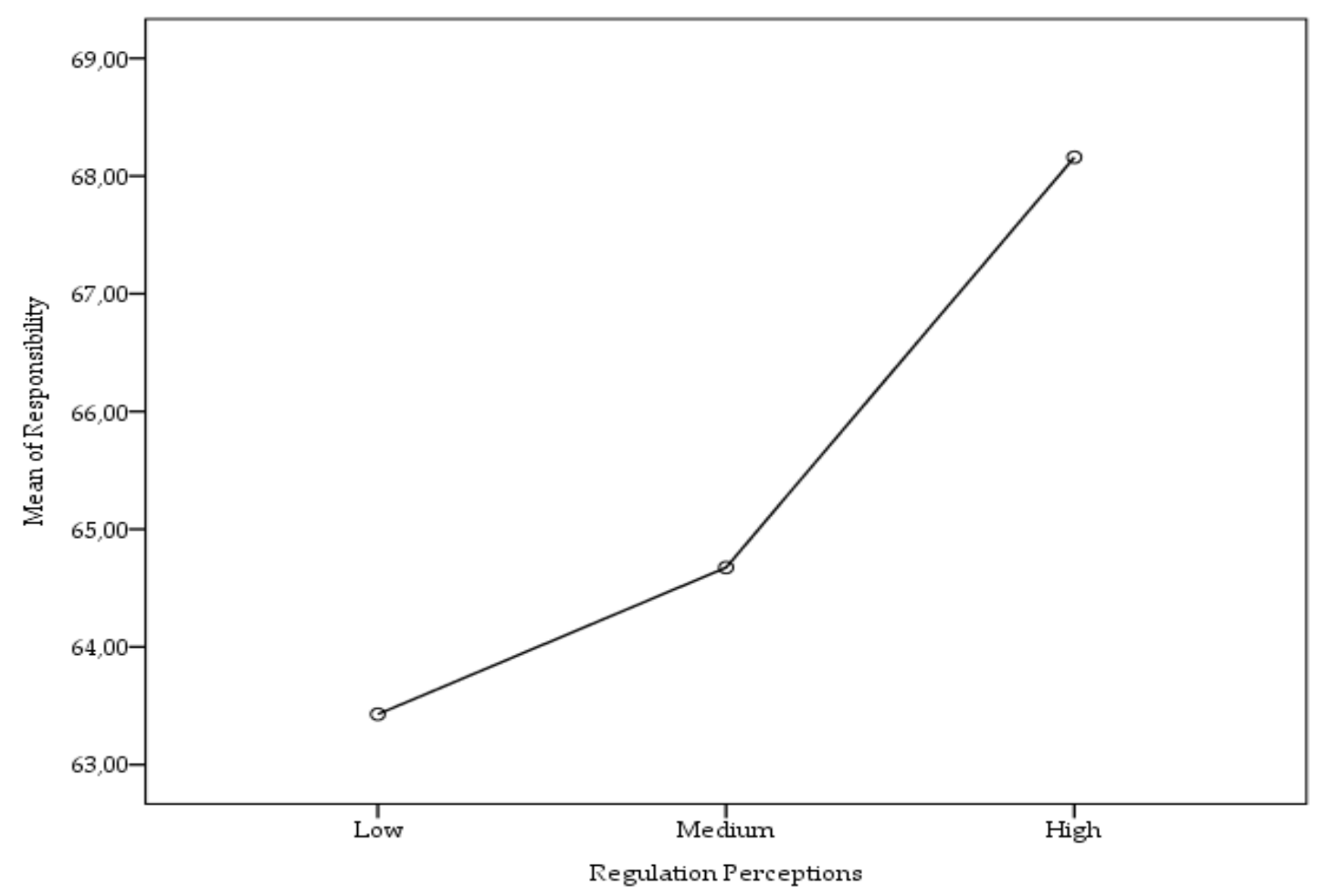

Figure 2. Responsibility levels of the students based on their Regulation Perceptions

Table 5.

Tamhane's T2 Test Results for Whether the responsibility of the students differ based on their Regulation Perception

\begin{tabular}{|c|c|c|c|c|c|c|}
\hline \multirow{2}{*}{$\begin{array}{l}\text { (I) Regulation } \\
\text { Perception }\end{array}$} & \multirow{2}{*}{$\begin{array}{l}\text { (J)Regulation } \\
\text { Perception }\end{array}$} & \multirow{2}{*}{$\begin{array}{l}\text { Mean } \\
\text { Difference (I-J) }\end{array}$} & \multirow{2}{*}{$\begin{array}{l}\text { Standard } \\
\text { Error }\end{array}$} & \multirow{2}{*}{$P$} & \multicolumn{2}{|c|}{ 95\% Confidence Interval } \\
\hline & & & & & Lower Limit & Upper Limit \\
\hline \multirow{2}{*}{ Low } & Medium & -1.24628 & .88502 & .427 & -3.4846 & .9920 \\
\hline & High & $-4.73080^{*}$ & .88727 & .000 & -6.9734 & -2.4882 \\
\hline \multirow{2}{*}{ Medium } & Low & 1.24628 & .88502 & .427 & -.9920 & 3.4846 \\
\hline & High & $-3.48453^{*}$ & .28542 & .000 & -4.1675 & -2.8015 \\
\hline \multirow{2}{*}{ High } & Low & $4.73080^{*}$ & .88727 & .000 & 2.4882 & 6.9734 \\
\hline & Medium & $3.48453^{*}$ & .28542 & .000 & 2.8015 & 4.1675 \\
\hline
\end{tabular}

As Table 4 and Table 5 displays, the responsibilities of the students differ significantly based on their regulation perceptions. Thus, it was concluded that the mean of the responsibility level score of the students with high regulation perception $\left(\overline{\bar{S}^{-}}=68.16\right)$ differs significantly from the students with medium regulation perception $\left(\overline{\bar{S}^{-}}=64.67\right)$ and with low regulation perception $\left(\overline{\bar{s}^{-}}=63.43\right)$. However, 
no significant difference was observed between the mean of the responsibility level score of the students with low regulation perception $\left(\overline{\bar{s}^{-}}=63.43\right)$ and that of students with medium regulation perception $\left(\overline{\bar{s}^{-}}=64.67\right)$. Besides, examination of Table 5 and Figure 2 revealed that the students with high regulation perception have higher responsibility levels as well.

\section{The relationship between the Responsibility Perception and Responsibility Level}

In this study the homogeneity of the variances of the scores were evaluated via Levene test to find out whether the responsibility levels of the 4 th grade students differ based on the responsibility perception. As the result of this analysis displayed that the variances were homogenous $[F(2,838)=4.032, p=.018]$, the results of the Welch test, which is an alternative to one-way analysis of variance, were taken into consideration. It is also found out that the results obtained from this test were crucial [Welch Test: $F(2$, $42.632)=73.777, p=.000]$. In addition, to determine which groups lead the significant difference for the responsibility levels Tamhane's T2 test, which do not deal with the assumption of homogeneity of the variances, was used and the related findings are presented in Table 7. Likewise, the findings on the responsibility levels of the students based on the responsibility perception were illustrated in Figure 3 .

\section{Table 6.}

Descriptive Analysis Results on the Responsibility Perceptions of the Students

\begin{tabular}{|c|c|c|c|c|c|c|c|}
\hline \multirow{2}{*}{$\begin{array}{l}\text { Responsibility } \\
\text { Perception Level }\end{array}$} & \multirow{2}{*}{$\mathrm{N}$} & \multirow{2}{*}{$\bar{X}$} & \multirow{2}{*}{ SD } & \multicolumn{2}{|c|}{ 95\% Confidence Interval } & \multirow{2}{*}{$\begin{array}{l}\text { Lowest } \\
\text { Score }\end{array}$} & \multirow{2}{*}{$\begin{array}{l}\text { Highest } \\
\text { Score }\end{array}$} \\
\hline & & & & Lower Limit & Upper Limit & & \\
\hline Low & 18 & 63.53 & 5.54 & 60.68 & 66.37 & 54 & 72 \\
\hline Medium & 344 & 63.96 & 4.21 & 63.52 & 64.41 & 53 & 72 \\
\hline High & 482 & 67.49 & 3.99 & 67.13 & 67.85 & 53 & 72 \\
\hline Total & 844 & 65.97 & 4.47 & 65.67 & 66.27 & 53 & 72 \\
\hline
\end{tabular}




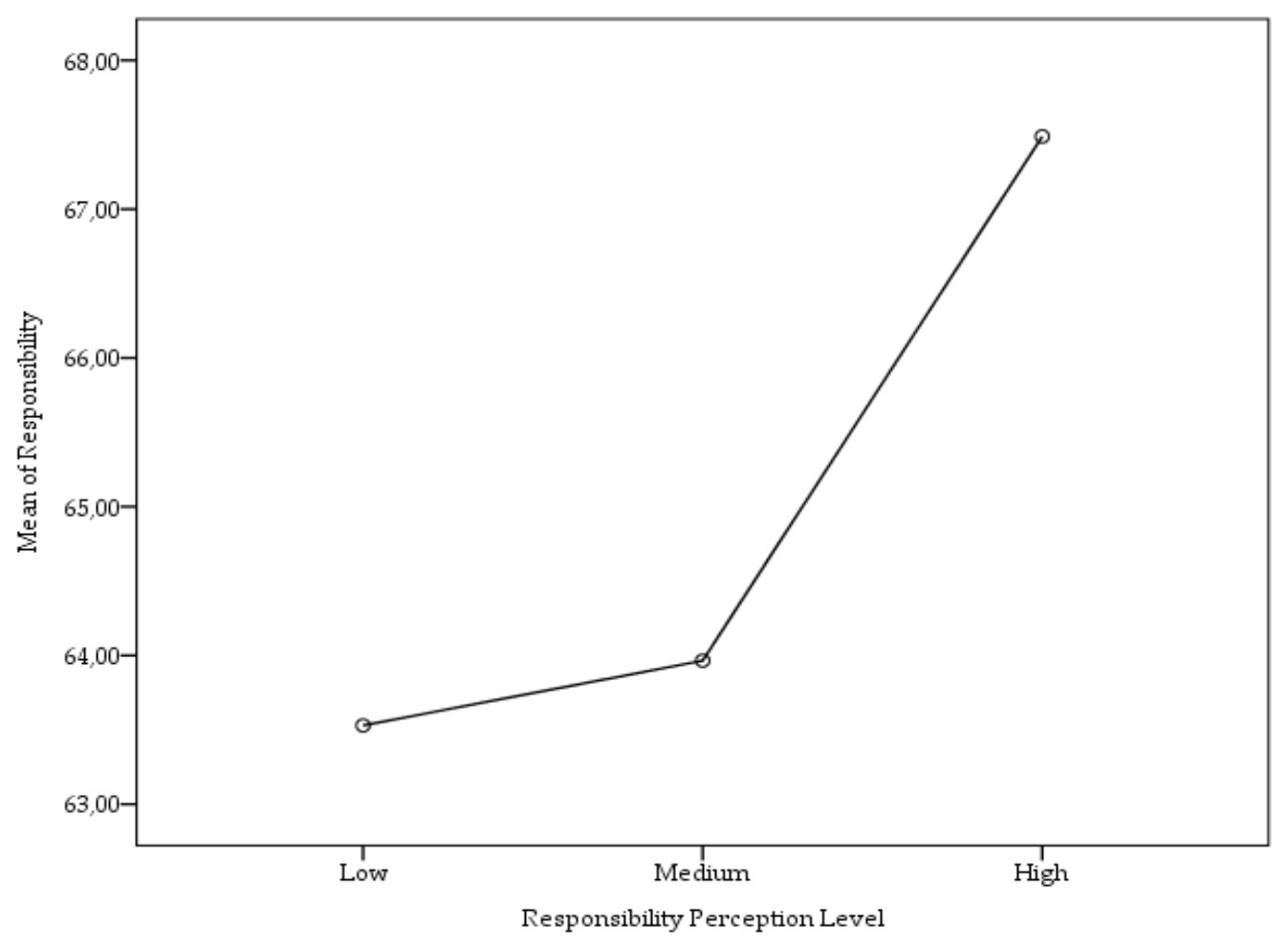

Figure 3. Responsibility Levels of the Students based on their responsibility Perception.

Table 7.

Tamhane's T2 Test Results for whether the Responsibility of the Students differ based on their Responsibility Perception

\begin{tabular}{|c|c|c|c|c|c|c|}
\hline \multirow{2}{*}{$\begin{array}{l}\text { (I)Responsibility } \\
\text { Perception }\end{array}$} & \multirow{2}{*}{$\begin{array}{l}\text { (J)Responsibility } \\
\text { Perception }\end{array}$} & \multirow{2}{*}{$\begin{array}{l}\text { Mean } \\
\text { Difference (I-J) }\end{array}$} & \multirow{2}{*}{$\begin{array}{l}\text { Standard } \\
\text { Error }\end{array}$} & \multirow{2}{*}{$P$} & \multicolumn{2}{|c|}{$95 \%$ Confidence Interval } \\
\hline & & & & & Lower Limit & Upper Limit \\
\hline \multirow{2}{*}{ Low } & Medium & -.43560 & 1.02355 & .913 & -2.9455 & 2.0743 \\
\hline & High & $-3.95915^{*}$ & 1.01659 & .001 & -6.4520 & -1.4663 \\
\hline \multirow{2}{*}{ Medium } & Low & .43560 & 1.02355 & .913 & -2.0743 & 2.9455 \\
\hline & High & $-3.52355^{*}$ & .29112 & .000 & -4.2374 & -2.8097 \\
\hline \multirow{2}{*}{ High } & Low & $3.95915^{*}$ & 1.01659 & .001 & 1.4663 & 6.4520 \\
\hline & Medium & $3.52355^{*}$ & .29112 & .000 & 2.8097 & 4.2374 \\
\hline
\end{tabular}

${ }^{*} p<0.05$ 
By examining Table 6 and Table 7 it can be seen that responsibilities of the students significantly differ based on the responsibility perception. Thus, it was found out that the mean of the responsibility level score of the students with high responsibility perception $\left(\overline{\bar{x}^{-}}=64.67\right)$ differs significantly from the students with medium responsibility perception $\left(\overline{\bar{x}^{-}}=63.96\right)$ and with low responsibility perception $\left(\overline{\bar{X}^{-}}=63.53\right)$. However, no significant difference was observed between the mean of the responsibility level score of the students with low responsibility perception $\left(\overline{\bar{x}^{-}}=63.53\right)$ and that of students with medium responsibility perception $\left(\overline{\bar{x}^{-}}=63.96\right)$. Besides, examination of Table 6 and Figure 3 revealed that the students with high responsibility perception have higher responsibility levels as well.

\section{RESULT and DISCUSSION}

In the recent study a positive and a significant relationship between the responsibility levels of the students and the school satisfaction and school attachment was found out. It was seen that school satisfaction and school attachment predicts the responsibility significantly. This finding indicates that school satisfaction and school attachment of the students who can take responsibilities and who fulfill their responsibilities are affected positively. In their studies Babadoğan (2003), Güner and Selçuk (2004), pointed out that the responsible individuals have the characteristics of being adapted to the life, fulfilling the responsibility both to themselves and to the others equally, using their sources freely, making their own decisions, admitting the consequences of their own feelings, thoughts and behaviors, being aware of the rights and liabilities of the others, taking the responsibility of every action, being compatible with the environment being happy and hardworking. These qualifications are also thought to support the academic success of the students. Hence, Golzar (2006) underlined that the responsibility levels of the academically successful students are also high. Hwang (1995) suggested that one of the main reasons of the academic failure for the students was individual irresponsibility. Rotter (1966) expressed that individuals evading their responsibilities are less successful, are less creative and experience more disappointments. Considering the examination of academic success on the basis of school attachment, Bellici (2015) found out that the school attachment levels of the academically successful students are higher than that of unsuccessful students in her study. Lee and Smith (1995) stated that students who are very successful also have very high school attachment levels. Sarı (2012), Anderman (2002) Hagborg (1994), Goodenow and Grady (1993) and Isakson and Jarvis (1999), mentioned that there is a positive relation between the students' sense of belonging to the school and their grade-point average - thus the students with a high sense of belonging to school have higher grade-point averages. Roeser, Midgley and Urdan (1996) established a relationship between the high sense of belonging and academic success. Firestone and Rosenblum (1988) discovered that students with low school attachment levels tend to come school late, have attendance problems, are not very successful at school and exhibit bad behaviors at school. Verkuyten and Thijs (2002), Jovanović and Jerković (2011) found out a positive relationship between academic success and school satisfaction. Baker (1998), Huebner and McCullough (2000), established a positive relationship between school satisfaction and academic self-efficacy. Önder and Y1lmaz (2012) stated that school satisfaction helps decreasing the disobedience of the students. All of these findings underline that there is a positive relation between the responsibility levels of the students and their school attachment and school satisfaction. The higher levels of the academically successful students not only get more respect and 
support from their family, teachers and friends but also feel more secure in the school environment. Therefore, it is thought that the students attach themselves to school and are more satisfied with their school.

In the study it is also found out that the responsibilities of the students differ significantly based on their regulation perception. It was observed that the regulation levels where the students see themselves are in direct proportion to their responsibility levels. This indicates that the students are objective in their own regulation perception which refers that teaching the students how to be planned and systematic contributes to their being responsible individuals. Duruhan and Demir (2005) emphasized that schools have a key role in adopting the habit of studying planned and systematic and of spending their free time effectively. Kahraman and Pedük (2014) found that positive perfectionism levels of the girls are higher than that of boys in their study which established the perfectionism levels of the gifted students.

In the recent study it was concluded that the responsibilities of the students significantly differ based on their responsibility perception and a direct proportion was observed between the responsibility levels they referred to themselves and the responsibility scores. This result can imply the objectivity of the students in their own responsibility perception. Sense of responsibility as a qualification gained through education (Gosselin, 2003; Hughes, 2001; Yeşil, 2013) is thought to a key requirement for being successful both during education and in the other phases of life (Brecke and Jensen, 2007; Clouder, 2009; Macready, 2009; Sierra, 2009). It is also thought that responsibility perception shares some similarities to self-efficacy which is one's belief in one's ability to accomplish a specific task. This belief affects the attempt of the individual towards the related task, continuity during that task, his/her motivation for that task and finally the performance through that task (Kotaman, 2008). If self-efficacy is not adequate, the individual can display some ineffective behaviors although he/she knows what to do (Alc1, 2007). Because if the human being do not believe in the expected results of his/her actions, he/she is reluctant in struggling against the difficulties in life and reacting to them (Akbulut, 2006; Üstüner, Demirtaş, Cömert and Özer, 2009). Likewise, the attitudes, perceptions and belief of the students towards a responsibility affect the accomplishment level for that responsibility. Romi, Lewis, Roache and Riley (2011) found out a positive relation between the responsibility perception of the students and his/her attitudes towards the activities at school. There are also some studies on the responsibility perceptions of the teachers and candidate teachers - apart from the students. Armor et. al., (1976) underlined that the students of the teachers with high responsibility perception are more successful. Hence, it can be implied that teacher's adaptation of positive responsibility perception influences the responsibility perceptions of the students. In their studies Akbaşlı (2010), Czerniak and Chiarelott (1990), Memişoğlu (2006), Woolfolk and Hoy (1990) established consistent relationships between the personality characteristics of the teacher and student behavior and learning level. With reference to the fact that responsibility perception is teachable (Glasser, 2005; Önal 2005; Tayll, 2006) supportive activities of the teachers on this perception is crucial. This indicates that responsibility levels of the students can be enhanced depending on the improvement of their responsibility perception. 


\section{REFERENCES}

Acar, M. C. (2012). Varoluş̧̧u yaklaşım odaklı sorumluluk eğitimi programının ilköğretim 8. sinıf öğrencilerinin sorumluluk düzeylerine etkisi (Master's thesis). Gaziantep Üniversitesi, Gaziantep.

Akbaş, O. (2008). Değer eğitimi akımlarına genel bir bakış. Değerler Eğitimi Dergisi, 6(16), 9-27.

Akbaşlı, S. (2010). Öğretmen yeterlilikleri hakkında ilköğretim denetçilerin görüşleri. Eurasian Journal Of Educational Research, 39, 13-36.

Alcı, B. (2007). Yıldız teknik üniversitesi öğrencilerinin, matematik başarılar ile algıladıkları problem çözme becerileri, öz yeterlik algılar bilişüstü özregulationleme stratejileri ve öss sayısal puanları arasındaki açıklayıcı ve yordayıcı ilişkiler örüntüsü (Doctoral dissertation). Yıldız Teknik Üniversitesi, SBE, İstanbul.

Akbulut, E. (2006). Müzik öğretmeni adaylarının mesleklerine ilişkin öz yeterlik inançları. Yüzüncü Yıl Üniversitesi Ĕ̆itim Fakültesi Dergisi, 3(2), 24-33.

Anderman, E. M. (2002). School effects on psychological outcomes during adolescence. Journal of Educational Psychology, 94(4), 795-809.

Armor, D., Conroy-Oseguera, P., Cox, M., King, N., McDonnell, L., Pascal, A., Pauly, E., \& Zellman, G. (1976). Analysis of the School Preferred Reading Programs in Selected Los Angeles Minority Schools. Santa Monica, CA: RAND.

Aydoğan, R., \& Gündoğdu, K. (2015). The reflections of a responsibility program prepared for primary school students: An action research. Ĕ̆itimde Kuram ve Uygulama, 11(3), 1061-1088.

Baker, J. A., Dilly, L. J., Aupperlee, J. L., \& Patil, S. A. (2003). The developmental context of school satisfaction: Schools as psychologically healthy environments. School Psychology Quarterly, 18(2), 206-221.

Babadoğan, C. (2003). Sorumlu davranış geliştirme stratejileri bağlamında öğrenen sınıf. Milli Ĕ̆itim Dergisi, 157.

Baker, J. A. (1998). The social context of school satisfaction among urban, low-income, african-american students. School Psychology Quarterly, 13(1), 25-44.

Bellici, N. (2015). Ortaokul öğrencilerinde okula bağlanmanın çeşitli değişkenler açısından incelenmesi. Abant İzzet Baysal Üniversitesi Ĕ̆itim Fakültesi Dergisi, 15(1), 48-65.

Brecke, R., \& Jensen, J. (2007). Cooperative learning, responsibility, ambiguity, controversy and support in motivating students. Insight: A Collection of Faculty Scholarship, 2, 57-63.

Büyüköztürk, Ş., Kılıç Çakmak, E., Akgün, Ö. E., Karadeniz, Ş., \& Demirel, F. (2014). Bilimsel araştırma yöntemleri. Ankara: Pegem Akademi Yayınları.

Casas, F., Bello, A., González, M., \& Aligué, M. (2013). Children's subjective well-being measured using a composite index: What impacts spanish first-year secondary education students' subjective well-being? Child Indicators Research, 6(3), 1-28.

Cemalciler, Z. (2010). Schools as socialisation contexts: Understanding the impact of school climate factors on students' sense of school belonging. Applied Psychology, 59, 243. 
Clouder, L. (2009).'Being responsible': Students' perspectives on trust, risk and work-based learning. Teaching in Higher Education, 14(3), 289-301.

Cüceloğlu, D. (2002). Anlamlı ve coşkulu bir yaşam için savaşçı. İstanbul. Remzi Kitabevi A.Ş.

Czerniak, C. M., \& Chiarelott, L. (1990). Teacher education for effective science instruction- a social cognitive perspective. Journal of Teacher Education, 41(1), 49-58.

Deveci, H., \& Selanik Ay, T. (2009). İlköğretim öğrencilerinin günlüklerine göre günlük yaşamda değerler. Uluslararası Sosyal Araştırmalar Dergisi, 2(6), 167-181.

Duruhan, K., \& Demir, S. (2005). Resmi ve özel ilköğretim okullarındaki eğitici kol çalışmalarının amaçlarına ulaşma düzeyine ilişkin öğrenci görüşleri. Sosyal Bilimler Enstitüsü Dergisi, 19, 175185.

Firestone, W. A., \& Rosenblum, S. (1988). Building commitment in urban high schools. Educational Evaluation and Policy Analysis, 10, 285-299.

Glasser, W. (2005). Responsibility, respect and relationships: Creating emotionally safe classrooms. Quality Educational Programs, Inc. Retrived 02.03.2018 from http://www.videocourses4teachers.com/courseDescriptions/Old\%20Syllabi/RRRSyllabusRev.pdf.

Goodenow, C., \& Grady, K. E. (1993). The relationship of school belonging and friends' values to academic motivation among urban adolecent students. The Journalof Experimental Education, 62(1), 60-71.

Golzar, A. F. (2006). İlköğretim 5. sinı öğrencilerine yönelik sorumluluk ölçeğinin geliştirilmesi ve sorumluluk düzeylerinin cinsiyet denetim odağg ve akademik başarıya göre incelenmesi (Master's thesis). Hacettepe Üniversitesi, Ankara.

Gosselin C. (2003). On the learning of responsibility: A conversation between Carol Gilligan and John Dewey. In Kal Alston (Ed), Philosophy of Education. 308-315.

Güner N., \& Selçuk, Z. (2004). Sınıf içi rehberlik uygulamaları (4. Baskı). Ankara: Pegem Yayıncılık.

Hagborg, W. J. (1994). An exploration of school membership among middle and high school students. Journal of Psychological Assessment, 12, 312-323.

Hökelekli, H., \& Gündüz, T. (2007). Üstün yetenekli çocukların değer yönelimleri ve eğilimleri. R. Kaymakcan, S. Kenan, H. Hökelekli, Ş. Arslan, \& M. Zengin (Ed.). Değerler ve Eğitimi. Değerler Eğitimi Merkezi Yayınları: İstanbul.

Huebner, E. S., \& McCullough, G. C. (2000). Correlates of school satisfaction among adolescents. Journal of Educational Research, 93(5), 331-335.

Hughes, C. (2001). Developing conceptual literacy in lifelong learning research: A case of responsibility? British Educational Research Journal, 27(5), 601-614.

Hwang, L. C. (1986). Locus of conrol in intellectual situations in American and Chinese. International Journal of Psychology, 21(2), 167,10. 
Isakson, K., \& Jarvis, P. (1999). The adjustment of adolescents during the transition into high school: A short term longitudinal study. Journal of Youth and Adolescence, 28, 1-26.

Jovanović, V., \& Jerković, I. (2011). School satisfaction among secondary school students-relations with school achievement and mental health indicators. Psihologija, 44(3), 211-224.

Kahraman, S., \& Pedük, Ş. (2014). 6, 7 ve 8. sınıf üstün yetenekli öğrencilerin mükemmeliyetçilik düzeylerinin belirlenmesi. Trakya Üniversitesi Sosyal Bilimler Dergisi, 16(2), 137-150.

Karakuş, C., Kartal, A., \& Çağlayan, K. T. (2016) İlkokul öğrencilerine göre sorumluluk. Ankara Üniversitesi Ĕ̆itim Bilimleri Fakültesi Dergisi, 49(1), 1-19.

Kotaman, H. (2008). Özyeterlilik inancı ve öğrenme performansının geliştirilmesine ilişkin yazın taraması. Eğitim Fakültesi Dergisi, 21(1), 2008, 111-133.

Lee, V. E., \& Smith, J. B. (1995). Effects of high school restructuring and size on early gains in achievement and engagement. Sociology of Education, 68, 241-270.

Macready, T. (2009). Learning social responsibility in schools: A restorative practice. Educational Psychology in Practice, 25(3), 211-220.

Memişoğlu, S. P. (2005). Sınıf ortamında istenmeyen davranışlara yol açan öğretmen davranışları. Çă̆daş Ĕ̆itim, 323, 32-39.

Mengi, S. (2011). Ortaöğretim 10. ve 11. sinı öğrencilerinin sosyal destek ve özyeterlik düzeylerinin okula bağlılıklarıyla ilişkisi (Master's thesis). Sakarya Üniversitesi, Sakarya.

Osterman, K. F. (2000). Students' need for belonging in the school community. Review of Educational Research, 70(3), 323-367.

Önal, Ş. H. (2005). Bir sorumluluk eğitim programının lise dokuzuncu sınıf öğrencilerinin sorumluluk düzeylerine etkisi (Master's thesis). Uludağ Üniversitesi, Bursa.

Önder, F. C., \& Yılmaz, Y. (2012). Ortaöğretim öğrencilerinde görülen kuraldışı davranışları yordamada yaşam doyumu ve anne-baba stillerinin rolü. Educational Sciences: Theory E Practice, 12(3), 17371748.

Randolph, J. J., Kangas, M., \& Ruokamo, H. (2009). The preliminary development of the children's overall satisfaction with schooling scale. Child Indicators Research, 2(1), 79-93.

Roeser, R. W., Midgley, C., \& Urdan, T. C. (1996). Perceptions of the school psychological environment and early adolescents psychological and behavioral functioning in school: The mediating role of goals and belonging. Journal Of Educational Psychology, 88, 408-422.

Romi, S., Lewis, R., Roache, J., \& Riley, P. (2011). The impact of teachers' aggressive management techniques on students' attitudes to schoolwork. The Journal of Educational Research, 104(4), 231240 .

Rotter, J. B. (1966). Generalized expectancies for internal versus external locus of control of reinforcemenf. Psychological Monographs, 80, 56 -67.

Sierra, J. J. (2009). Shared responsibility and student learning: Ensuring a favorable educational experience. Journal of Marketing Education, 32, 104-111. doi: 10.1177/0273475309344802. 
Samdal, O., Wold, B., \& Bronis, M. (1999). Relationship between students' perceptions of school environment, their satisfaction with school and perceived academic achievement: An international study. School Effectiveness And School Improvement, 10, 296-320.

Sarı, M. (2012). Sense of school belonging among elemantary school students. Çukurova Üniversitesi Ĕ̈itim Fakültesi Dergisi, 42(1), 1-11.

Savi, F. (2011). School attachment scale for children and adolescents: The study of validity and reliability. Ilköğretim Online, 10(1), 80-90.

Taşdemir, M., \& Dağıstan, G. (2014). Çocuklara sorumluluk kazandırmada ebeveynlerin bhtg yaklaşımını uygulama durumları: Bir durum çalışması. Turkish Studies - International Periodical For The Languages, Literature and History of Turkish or Turkic, 9(8), 47-71.

Taylı, A. (2006). Akran yardımcılı̆̆ı uygulaması aracılı̆̆ıyla lise öğrencilerinde kişisel ve sosyal sorumlulŭ̆un arttırılması (Doctoral dissertation). Gazi Üniversitesi, Ankara.

Tepecik, B. (2008) Sosyal bilgiler dersinde sorumluluk değerinin kazandırılmasına ilişkin öğretmen görüşleri (Yüksek Lisans Tezi). Eskişehir Anadolu Üniversitesi, Eskişehir.

Uzunkol, E. (2015). Sayg1 ve sorumluluk değerinin öğretimi. M. Gündüz (Ed.) Değerler Eğitimi. Ankara: Maya Akademi.

URL,

1. Milli Eğitim Temel Kanunu, 2/2. http://mevzuat.meb.gov.tr/html/temkanun_0/temelkanun_0.html'den $\quad$ 01.03.2018 tarihinde alınmıştır.

URL, 2. Milli Eğitim Kanunu, m.11. http://mevzuat.meb.gov.tr/html/temkanun_0/temelkanun_0.html'den $\quad$ 01.03.2018 tarihinde alınmıştır.

Üstüner, M., Demirtaş, H., Cömert, M., \& Özer, N. (2009). Ortaöğretim öğretmenlerinin öz-yeterlik algıları. Mehmet Akif Ersoy Üniversitesi Ĕ̆̈itim Fakültesi Dergisi, 9(17), 1-16.

Yavuzer, H. (1997). Anne-baba ve çocuk. İstanbul, Remzi Kitabevi

Yeşil, R. (2013). Ortaöğretim öğrencilerinin okul öğrenmelerindeki öğrenme sorumluluklarını yerine getirme düzeyleri. Uluslararası İnsan Bilimleri Dergisi, 10(1), 1214-1237.

Verkuyten, M., \& Thijs, J. (2002). School satisfaction of elementary school children: the role of performance, peer relations, ethnicity, and gender. Social Indicators Research, 59(2), 203-228.

Woolfolk, E. A., \& Hoy, K. W. (1990). Prospective teachers' sense of efficacy and beliefs about control. Journal of Educational Psychology, 82(1), 81-91.

Yontar, A.(2007). Sorumluluk eğitiminde ceza uygulamalarına ilişkin ilköğretim 5. sinıf öğretmen ve öğrenci görüşlerinin incelenmesi (Master's thesis). Çukurova Üniversitesi, Adana. 